\title{
Monetary Correction: a Timeline about the Tool Use, from 1944 to 1995.
}

Ariovaldo dos Santos

Full Professor, Department of Accounting and Actuarial Science, School of Economics, Business and Accounting, University of São Paulo.

E-mail: arisanto@usp.br

\section{ABSTRACT}

This article works with the history of how the tool inflation adjustment of annual reports was arranged over half a century until its extinction. To do this, we related the social contexts, the legislation, and the academic perception corresponding to its best implementation in the financial system of Brazil. This study introduces a chronology of using this tool since the 1940s, when a sporadic revaluation of assets began, until the 1990s, when the signs of fatigue and the very extinction of inflation adjustment became apparent in Brazil. The importance of this historical contextualization relies on the possibility of understanding the history of inflation adjustment related to recent events in the country's history, marked over these 50 years by troubled times in national politics, permeated with strong instabilities. The Brazilian economy has faced, in its recent history, long periods of high inflation rates. Several measures and plans were needed to reduce inflation rates and seek economic stability. Even so, it was observed that, in the first moments when the country experienced a less severe inflation process, compared to some later ones, there was support from a regulatory legislation and concern to measure and mitigate the impacts of devaluation of the currency's purchasing power on the assets of companies. Thus, we also point out the limits imposed by the prohibition to use this tool to deal with the lack of accuracy of annual reports prepared by companies since 1996.

Ǩeywords: Inflation. Monetary Correction. Indexation. Timeline. Economic history. 


\section{INTRODUCTION}

Over its history, the Brazilian economy has faced long periods of severe inflation rates. Many measures and plans were needed to reduce inflation rates and seek economic stability. Therefore, considering the economic history of contemporary Brazil, inflation has been a major issue of concern among economists, accountants, financial administrators, and the population as a whole. This paper seeks to evaluate how, over time, inflation adjustment was arranged through legal parameters and studied by academic research. During the analysis of this process, we also introduce a chronological division marked by a different historical and economic contextualization, composing what we conceive as a chronology of using this tool for 50 years in our history.

To conciliate economic growth and development of companies and institutions, it was needed to create financial compensation mechanisms in order to adjust the loss of currency's purchasing power caused by inflation. Thus, the inflation adjustment mechanism was created, which ended up becoming part of people's daily lives and, as a consequence, companies' daily lives. This tool was created so that there was no decapitalization of private citizens or legal entities and, therefore, it was responsible for creating some stability in a daily life surrounded by uncertainties. We cannot forget: the "institution" inflation adjustment was observed in rental agreements, loans, purchase and sale of movable and immovable property, wage negotiations, tax payments, in short, in all economic activities. In other words, considering inflation in annual reports was just another way of coping with the inflationary environment where we operated.

Thus, it becomes important to survey and study the discussions that took place in Brazil for decades concerning mechanisms to valuate companies' equity by historical cost, monetarily adjusted. This situation - both in practice and academic studies - prevailed in much of the last century.

It is worth saying that several studies in economic history have highlighted the effects of inflation and the debate on inflation adjustment in annual reports, given its impact on the set of reforms implemented through economic policy, during the years of military dictatorship - from 1964 to 1984 . However, in this article, we are interested in addressing this instrument over the history of the $20^{\text {th }}$ century, introducing a chronology of its various contexts, as its emergence may be dated back to the 1940s and its "extinction" may be linked to the control of inflation promoted by the implementation of Brazil's Plano Real, in the mid-1990s. This way, we can see that inflation adjustment was, over much of the $20^{\text {th }}$ century, an instrument of paramount importance to understand economic events, with social and political effects for the Brazilian population.

During the five decades covered by the analysis described in this article, Brazil observed the emergence of a legislation that regulated the use of inflation adjustment in order to mitigate the negative impacts of inflation on companies' life and, as a consequence, on annual reports.

Thus, this article, besides contributing to understand the dissemination of economic ideas by taking into account the Brazilian recent economic history, outlines a history of the legislation that has supported and standardized the application of inflation adjustment and, thus, it provides a record of the importance of studying and applying inflation adjustment to business economy. The chronology proposed herein is based on studying the legislation on inflation adjustment.

\section{A CHRONOLOGY OF INFLATION ADJUSTMENT}

In order to think through the history of this mechanism, we address various contexts where inflation adjustment was used. In the recent Brazilian history, we highlight the period between 1943 (establishment of the first regulation on inflation adjustment) and 1995 (solidification of Brazil's Plano Real and prohibition to consider inflation in financial statements). Thus, the division proposed herein has 6 periods that may be understood as follows: 1944-1957 - Sporadic Revaluation of Assets; 1958-1964 - Permanent Adjustment of Assets; 1965-1976 - Development of the Inflation Adjustment Systematics; 1977-1984 - Maturing of Inflation Adjustment in Brazil; 1985-1988 - Intervention by the Brazilian Securities and Exchange Commission (CVM) in the Inflation Adjustment Methodology - Implementation of Full Inflation Adjustment (CMI); and 1989-1995 - Signs of Fatigue and Extinction of Inflation Adjustment in Brazil.

The chronology introduced herein has been based on the use that the tool of inflation adjustment of annu- al reports took at various times over the recent history of Republican Brazil. Marking out these periods was also defined having the historical and economic context that allowed a certain use of this tool as a basis. Nevertheless, going beyond, the chronological division proposed herein is based on the legislation that anchored and improved, over these 50 years, the use of inflation adjustment as an instrument. Thus, it is worth showing how each period was arranged, its main characteristics, and a selection of the main laws that allowed this history to unfold.

\subsection{4-1957 - Sporadic Revaluation of Assets 2.1.1 Historical and economic context}

The first period proposed herein began while Brazilian troops were participating in World War II, and its milestones are the years 1944 and 1957. The strategy adopted during Brazil's Estado Novo to raise external funding in return for supporting the Allies, in order to create Com- 
panhia Siderúrgica Nacional (CSN), involved concerns to ensure conditions for the development of the national economy. However, in 1945, due to the war's end, Getúlio Vargas was pressed to end the Estado Novo and call direct elections, besides convening a new Constituent Assembly. Temporarily, José Linhares - President of the Brazilian Supreme Court (STF) - assumed the Brazilian presidency until elections were held. Eurico Gaspar Dutra took the federal government in January 1946 and he implemented an economic policy that led Brazil, from then on, to cope with a high volume of imports of goods. This helped, a lot, to lead Vargas back to power in 1951. Taking into account that, at that time, the country was facing an inflationary process, the government outlined its economic policy supported by a project that aimed to: provide economic stability by using fiscal and monetary policies as pillars (Campos, 2003).

Liberalization in the concession policy, adopted by the previous government, impacted the national reserves and economy. Faced with this, on August 1, 1951, the council of the Superintendency of Currency and Credit (SUMOC) set a stricter licensing regime, it stated regulating better the country's entry and exit of capital, as a proof of its nationalist policy. However, the outcomes of these measures took over a year to reflect a reduction in the import statistics.

In the first half of 1953 came into force Law 1,807 (Free Market Law), which aimed to increase exports and decrease imports. Nevertheless, political instability was great, so much that the president committed suicide in 1954. Café Filho took office, but the problems with inflation and trade deficit also strongly affected his administration.

The following year, Juscelino Kubitschek de Oliveira was elected and took office in 1956, with a developmental plan based on what was named Plano de Metas, which sought to provide the growth of 50 years in 5 . His administration came along with major economic growth and strong industrialization funded by foreign capital, marking a break with Vargas' economic policy. Inflation began to manifest as a social problem.

At that time, the possibility of performing a "sporadic revaluation of assets" began. The term "revaluation" may denote a conceptual ignorance that is easily criticized today, but at that historic moment it was the most acceptable concept.

Thus, inflation adjustment in annual reports was "deployed" in Brazil as a sporadic revaluation of fixed assets, and the effects of this inflation adjustment were considered when determining profit that served as the basis for calculating income tax. At that time, the periods of application and the adjustment rates were determined arbitrarily.

\subsubsection{Legal context}

The starting point of this period was the entry into force, in January 1944, of Decree-Law 5,844/43, which allowed the revaluation of fixed assets of legal entities under specific circumstances. The result of this revaluation was taxed by the standard rate of income tax.

The following year, Decree-Law 7,377/45 (on the website of the House of Representatives there is the information that this decree-law was not declared null and void) authorized the mutual insurance companies to consider, among its assets, the recognition of immovable property up to its sale value.

In 1947, Law 154 added an item to Article 43 of Decree-Law 5,844/43 determining that the taxation standard, to calculate actual or expected profit, would be added with the corresponding increase in the asset value, due to the new valuations. Here, it is noteworthy that, since that time, legislation refers to "actual or expected profit". Moreover, the law stipulated that the valuation should remain, at most for a 4-year period, protected from liabilities by a revaluation fund, until they were added to actual profit.

Law 1,474/51 provided for capital increase through revaluation of fixed assets, restricted to the case of companies with their equity capital paid up, and they must not use revaluation as payment or pay up for shares or quotas.

In 1952, Law 1,772 established the exceptional taxation on capital increase resulting from the incorporation of revaluation reserve of assets valuated up to June 30, 1953.

Law 2,862/56 authorized capital increase through the revaluation of fixed assets, acquired up to December 31, 1950, as well as the incorporation of taxable reserves established up to December 1956 and it set revaluation coefficients. It prohibited depreciation or amortization of the revaluation amount, which should be highlighted in the accounting records. Capital increase, both by revaluation and incorporation of reserves, should be taxed, so that the resulting tax would be paid within three years; indeed, without paying this tax, companies could not reduce their capital, be incorporated into other companies, merge, dissolve, or terminate (except in the case of bankruptcy). The sale of revaluated assets for less than five years was also taxed.

\subsubsection{Context of academic research}

According to reflections by Wald, Simonsen and Chacel (1970, p. 65), inflation created three primary distortions in companies' balance sheets: undervaluation of fixed assets, booked in currency with no adjustment for decline in purchasing power; failure of depreciation that, calculated having nominal historical costs of equipment and installations as a basis, became insufficient to meet the needs for replacing them; and the generation of illusory profits that, in fact, represented nothing but the provision needed to keep the actual value of working capital.

At the time when decline in a currency's purchasing power occurs, it is reflected in the monetary items of the balance sheet, preventing them to be compared, in terms of currency as a measure of value, to the other items, those that are non-monetary. As non-monetary items are booked in currency at original value, there is a need to adjust these balances. Adjustment is ultimately perfect when all non-monetary items are adjusted (Famá, 1980, p. 172). 
It may be said that these early regulations addressing on an embryonic basis something that, decades later, has been named "inflation adjustment" sought to mitigate only the first distortion cited by Wald et al. (1970). Law 1,474/51 did not allow the company to decrease its capital without paying the required tax. This principle was intended to preserve the right of creditors of a legal entity undergoing revaluation, because using it to pay up for shares implies reducing (in actual terms) the capital with which shareholders had committed to contribute to the company, i.e. the guarantee to its creditors (Wald et al., 1970, p. 66).

Such legal provisions did not have as a final foundation the replacement of assets, and they also did not aim to demonstrate its decapitalization to the administration, as this legislation did not allow the adjustment of depreciation or amortization values (Famá, 1980, p. 67). In fact, revaluation did not imply any effect on the reported profit and the income tax (Doupnik, 1987, p. 112).

As revaluation was not mandatory, the decision to perform it was made as a matter of tax planning, due to the fact that it is taxed, the companies were subject to this tax only to escape the violence of tax on extraordinary profits. Many researchers believe that most companies did not regard revaluation of their fixed assets as an advantage (Doupnik, 1987, p. 113).

Thus, another research, conducted by Chacel et al. (quoted by Doupnik, 1987, p. 113), explained that this prohibition (depreciation of value of fixed assets adjusted for inflation) derived from the immediate needs of National Treasury, because depreciation might reduce revenue with the income tax.

According to Famá (1980, p. 67), in fact, the main aim of the "adjustment" of balance sheets until 1964 was raising more funds for the public coffers. To some extent, it might be paying the government a tax whose cause was finding out variation in value, due to various situational factors.

Wald et al. (1970, p. 66) revealed that the main function of revaluation within this period was adjusting the fixed capital invested in the company for inflation, in order to determine the taxable surplus profit, regarding the profit beyond share capital plus reserves. The same authors point out two foci of tax injustice concerning this tax on extraordinary profits: the first due to profits inflated by two illusory components, non-booked adjustment of depreciation and maintenance of working capital; the second because capital was undervalued by bookkeeping in currency with no adjustment for decline in purchasing power.

\subsection{8-1964 - Permanent Adjustment of Assets \\ 2.2.1 Historical and economic context}

The year opening this new period is marked by achievements, in FIFA World Cup, in Bossa Nova, and in industrialization. In 1959, the first car manufacturer was inaugurated in Brazil, in São Bernardo do Campo, São Paulo. And the following year, soon after the installation of the federal capital in Brasilia, Brazil was granted a loan of nearly $\$ 48$ million from the International Monetary Fund (IMF).

Since the resignation of Jânio Quadros, in August
1961, Brazil experienced great political instability. It replaced the presidential with the parliamentary system to allow João Goulart, Jânio’s elected vice president, to take office as president. The regulation of foreign capital and the defense of Reformas de Base [grassroots reform] made Jango's position even weaker and gave room for the military coup in 1964.

Many historians regard 1964 as the official year of the emergence of inflation adjustment. Within this period, revaluation of companies' fixed assets was translated from an occasional practice into a continued practice among companies, already named inflation adjustment. Until then established as non-mandatory and "primitive", it enters a phase of mandatory inflation adjustment of fixed assets; when the military government took office, in 1964, inflation adjustment regarding the depreciation of these assets was established.

In addition to inflation adjustment of depreciation, Law 4,357/64 authorized companies to deduct from the taxable surplus profit the amount that corresponds to the maintenance of their own working capital.

\subsubsection{Legal context}

Law 3,470/58 allowed companies to adjust the accounting record of the original value of assets of their fixed assets based on coefficients determined by the National Economics Council every two years. This adjustment could be made to at any time, up to the limit of coefficients then prevailing. The law established that the coefficients should be calculated in order to express the variations in purchasing power of the national currency and, thus, this operation came closer to inflation adjustment, detaching from what had initially been proposed as a revaluation of assets. Inflation adjustment was limited by the difference between applying the coefficient to the accounting record of the original value of each asset and amortizations booked from acquisition to adjustment, adjusted by the same coefficients, according to the year of their accounting records. Nevertheless, the amount of adjustment should be included in the accounting records in a different way from the asset and it should not be computed for the purpose of depreciation or amortization. The counterpart of increase in the asset should, mandatorily, be registered as capital increase, but never as pay up for shares or quotas. The assets corresponding to aid, subvention, or other non-required public resources should not be adjusted.

Law 4,242/63 determined that sharing-economy companies, whose shares were part of the National Investment Fund's portfolio, should adjust on an annually basis their fixed assets and the National Economics Council would start setting, on an annually basis, the coefficients to calculate the adjusted value of assets.

The following year, Law 4,357/64 determined the mandatory annual indexation of fixed assets, in accordance with the coefficients annually set by the National Economics Council. The result of inflation adjustment should be registered in the "Non-Required Liabilities" and incorporated into the company's capital 4 months 
after the date of the balance sheet closing that corresponded to the adjustment made; it was allowed to constitute a capital reserve if the increase was greater than 3 times the value of booked capital, however, this reserve should be incorporated into the capital within a period of up to 5 years. Instead of paying income tax on the adjusted value of assets, the taxpayer could choose to acquire National Treasury Bonds (OTNs), having a deadline over 5 years, at an updated nominal value corresponding to twice what might be taxed; OTNs acquired this way became nominal and non-transferable for a period of 5 years. To calculate the additional income tax, in relation to the capital of legal entities, companies could deduct from taxable surplus profit the amount corresponding to the maintenance of their own working capital during the fiscal year of its statement. Decree 54,145/64 regulated Law 4,357/64 with regard to inflation adjustment, among other issues, and established that: for the purpose of indexation, the assets purchased for resale or gathered for sale, the assets intended to guarantee the technical reserves of insurance or capitalization companies, and the participation in other companies that adjusted the value of assets should not be included as part of the fixed assets.

Law 4,380/64 established inflation adjustment in real estate contracts having social interest, related to the financial system and housing of social interest.

Decree 54,252/64 renamed the OTNs, which became "Treasury bonds - readjustable type", which were shortly termed as "readjustable bonds". This decree also established that the nominal value of a readjustable bond would be updated each quarter and the private citizen required to pay income tax could choose to submit readjustable bonds in an amount corresponding to twice the taxed value.

Law 4,506/64 established that, since January 1, 1967, inflation adjustment of companies' fixed assets, performed in accordance with Article 3 of Law 4,357, enacted on July 16,1964 , should suffer no financial burden related to tax or compulsory loan.

Decree 54,936/64 regulated inflation adjustment of fixed assets of concessionaires of electricity services, taking into account that the income derived from tariffs structured on the basis of historical cost of booked investment does not represent the actual cost of service due to the inflationary phenomenon, so that the service provided below the actual cost represents an actual loss to the national economy.

Law 4,481/64 established that legal entities should readjust the company's capital according to the inflation adjustment of fixed assets until 30 November, 1964.

It is worth noticing that this legislation, even in an incipient manner, has paved the way for the formal and standardized organization of inflation adjustment as a tool.

\subsubsection{Context of academic research}

Clearly, at this early stage, the key purpose of rules was not leading the annual reports to show the actual financial status of companies (Gonzáles, 1999, p. 69). Famá (1980 quoted by Gonzáles, 1999) thought that the purpo- se of these standards was not replacing assets or creating a mechanism to allow demonstrating to management the decapitalization that equity was undergoing, since these laws did not allow adjusting the values of depreciation and amortization.

Wald et al. (1970, pp. 117-118) show the impact of creating the automatic mechanism of inflation adjustment for fixed assets in the stock market. Since this mechanism has led companies to distribute many bonuses to their shareholders, there was a substantial increase, not only in nominal terms but also in actual values, the average share price between 1959 and 1960.

\subsection{5-1976 - Development of the Inflation Adjustment Systematics}

\subsubsection{Historical and economic context}

Some studies pointed out the specificities of economics in the new context experienced after the major political and social changes in the first half of the 1960s. According to the Brazilianist Thomas Skidmore (1988, p. 68), "by any calculations, the Brazilian economy was going thought extreme difficulties in 1964".

Economic historians point out that, in 1964, the government identified inflation as a primary problem of the Brazilian economy, diagnosing it as demand inflation, sanctioned by excessive monetary expansion. Therefore, between 1964 and 1966, the government deploys tough measures in the fiscal and monetary fields.

During the crisis that affected politics, there was some stabilization in the economy. Between 1965 and 1970, the country experienced what was named "Brazilian miracle", a period marked by strong economic growth. Gains in fighting inflation are no longer as significant and government has admitted a certain level of inflation. Furthermore, government controlled price adjustments based on the variation of costs.

Within this period, many innovations were introduced, mainly with regard to the inflation adjustment system. The reserve for maintenance of working capital was created and the depreciation of adjusted value of assets started being accepted.

In this delicate context, an instrument of undeniable importance was improved: inflation adjustment in annual reports. As highlighted by Celso Furtado (1972, p. 51),

[...] by means of a particular policy of price, exchange, and credit and the mechanism of inflation adjustment it is possible to guide inflation - process of income distribution change - so that the redistributive effects do not take place in a chaotic way, but due to predetermined aims.

It is worth recalling that inflation adjustment was an instrument of economic policy that hit all social classes, although not uniformly. This tool was used to update the value of companies' capital in the productive sector or for the calculation of tariffs of public services, funding, rents, taxes, and, although not to the same extent, as a reference for wage adjustment. 


\subsubsection{Legal context}

Law 4,663/65 granted tax benefits for the companies that showed exceptional rates of restriction on price increase, among these benefits there was the possibility to deduct the maintenance of working capital from taxable surplus profit and the reduction of tax on inflation adjustment of fixed assets.

Law 4,728/65 recognized the outcome of inflation adjustment of fixed assets and maintenance of working capital as "resources owned" by the company for setting the limits to access the national financial system (in the case of companies that had access to the international financial market) as a measure against an occasional unbalanced payment balance sheet. Within the regulation of inflation adjustment, the law allowed companies to include the net outcome of adjusted value of fixed assets and their own working capital into the company's capital or reserves.

Law 4,862/65 established that the progressive ranges of income tax should be annually updated by inflation adjustment coefficients set by the National Economics Council. The value of immovable property, for the purpose of adjusting values, could be reduced at the taxpayer's discretion, at the same proportion existing between the minimum wage in the area where they were located and the highest minimum wage in the country. The importance of adjusting the cost to acquire or plant forest resources exploited by companies might be necessarily preserved by the company, due to the non-required liabilities, and it should also be highlighted among the assets, in a special account.

Decree-Law 62/66 authorized companies to adjust to inflation, along with accounts of fixed assets (with the respective depreciation), the capital owned (equity) and the credits and liabilities subject to inflation adjustment. The adjustment of fixed capital was calculated having monthly price rates stated by the National Economics Council as a basis, and the investments in other companies were adjusted by their original acquisition cost. Equity accounts were updated by their opening balance within the fiscal year increased or decreased by prior year adjustments, whose variations were added to the balance of each account, except the paid up company's capital where the capital adjustment account was created, which might serve to compensate losses or increased capital, without burden of income tax for partners or shareholders. Variations in liabilities in foreign currency were registered up to the limit of increase in assets resulting from the adjustment, after compensating adjustments in the equity account. The counterparts to adjustment of assets and liabilities started being taken to the account "inflation adjustment of the balance sheet".

Decree-Law 401/68 authorized companies to deduct from taxable profit the amount corresponding to the maintenance of their own working capital during the fiscal year of its statement, determined by the application, on the working capital in beginning of the fiscal year, the adjustment percentages set by a portaria by the Minister of Planning and General Coordination. The working capital owned by the company was regarded as the available assets plus the realizable assets (less the items in foreign currency or subject to inflation adjustment, participation in other companies, and unpaid balance of company's capital), less the required liabilities. The adjustment was launched as credit in the appropriate account of non-required liabilities and in the account of profits and losses, in order to be added to the company's capital within 120 days. It was also authorized that, until April 30, 1969, the legal entities could restate the bookkeeping of their stocks of goods, raw materials, manufactured products or manufacturing materials, included in balance sheets closed until December 31, $1968^{1}$.

Decree-Law 433/69 limited the application of maintenance of working capital when the adjustment represented a reduction over $20 \%$ of the taxed value and in the cases where the company's balance closed with losses. It also authorized, when the National Monetary Council deemed indispensable, taking into account the State taxation and the financial situation, the Minister of Finance to limit the application of maintenance of working capital as a reduction of taxed due.

Decree-Law 973/69 and the Supplementary Normative Act 74/69 addressed the application of inflation adjustment to port concessionaires.

Decree-Law 5,760/71 established that the calculation of inflation adjustment would not cover, in any case, the period before the date on which the law that established it came into force.

In 1971, by means of Decree-Law 1,182, the Commission of Merger and Incorporation of Companies (COFIE) was created, with the assignment to assess the processes of revaluation, merger, and acquisition of companies operating in the country. In order to encourage mergers, incorporations, and opening of companies' capital, authorized, for the purpose of merger or incorporation regarded as of interest to the national economy, companies to revalue the assets included in the fixed assets above the limits of inflation adjustment, until the market value, with exemption from the income tax related to the added value, resulting from this revaluation.

Decree-Law 1,302/73 changed the systematics of inflation adjustment of fixed assets and the calculation of the maintenance of working capital. Variation in the value of fixed assets (difference between the original acquisition price or merger and the new currency translation) should be booked in the account of the assets with its own title, i.e. "Adjusted Active Assets". The adjustment should be done so that the difference between the new currency translation and the values already booked for inflation adjustment in previous years should be credited in the account of Inflation Adjustment of Depreciation, up to the limit of that difference, a value sufficient to equal the sum of inflation adjustments of depreciations and the depreciation of inflation adjustments of the asset to the same existing proportion as the depreciation of the original value of acquisition or merger of the assets, and the original value of these goods; net outcome, after realizing the credit, might be brought to the account "Inflation Adjustment Reserve". 
Revenues and expenses derived from assets and liabilities operations subject to inflation adjustment should, if debtors constitute operating expenses; if creditors, constitute non-taxable revenue and be subtracted from the Reserve for Maintenance of Working Capital calculated for the fiscal year. To calculate this reserve, the working capital owned by the company started being regarded as: the available assets plus the realizable assets (less the ite$\mathrm{ms}$ in foreign currency or subject to inflation adjustment, participation in other companies and unpaid balance of the company's capital), less the required liabilities (less negative balances of loans in foreign currency and loans subject to updating, both linked to the acquisition of fixed assets that were subject to inflation adjustment).

Decree-Law 1,338/74 started regarding, as taxable profit, the revenue from inflation adjustments, including those resulting from assets and liabilities subject to monetary and exchange rates. By considering working capital owned by the company as the sum of non-required liabilities (less unpaid losses, unpaid portion of company's capital, and tranches corresponding to provisions and depreciations) less the values of net fixed assets of depreciation (plus values derived from shareholding in other companies and any other accounts representing assets that were subject to adjustment of fixed assets); the reserve for maintenance of working capital owned by the company would be up to the limit of profits made during the fiscal year. Adjustments were made on the basis of the same coefficients used for updating Readjustable National Treasury Bonds (ORTNs).

\subsubsection{Context of academic research}

Until the enactment of Law 4,357/64 any regulation of inflation adjustment systematics was primarily grounded in three points. First, the cost of fixed assets was updated with the application of a coefficient set for the year of acquisition or manufacture of this asset. Obviously, this caused a gap of at least a year in updates, since acquisitions in January had the same treatment than those acquired in December. Second, depreciation, amortization, and termination were updated by using rates set for the years when they were booked. Thus, over the asset's useful life, there was a huge disproportion between cost depreciation and the corresponding cost inflation adjustment. Finally, the outcome of these updates, addressed as Inflation Adjustment Reserve, was booked only after the balance sheet closing, and this further increased distortions.

Subsequently, there are three decrees marking significant changes, which may be evidence of phases in the history of inflation adjustment within this period:

- A first phase may be marked by the regulation of Law $4,728 / 65$, which changes the scenario, because tax issues were established in Working Capital Adjustment. This change is due to the elimination of required incorporation to the company's capital of the outcome of ad- justment, but the taxation of an occasional reserve formed by inflation adjustment in the amount exceeding the company's capital remained.

- Another phase begins with the approval of Decree-Law 401/68, which started regulating the Reserve for Maintenance of Working Capital. This decree changed the method to calculate the maintenance of working capital, where debts in foreign currency would not be subtracted from the required liabilities for the purposes of calculating the working capital subject to adjustment, and such maintenance should be incorporated to the company's capital within 120 days. Santos (1980) emphasizes that, in 1973, with the publication of Decree-Law 1,302, the depreciation failure pointed out earlier was corrected, but others remained.

- In a third phase, we can see, in the regulation of Decree-Law 1,338/74, the recognition of gains on inflation. Thus, in 1974, government introduced other changes and the most significant ones set the profit within the period as the limit for constituting the reserve for maintenance of working capital, besides regarding it as negative. Santos (1980, p. 19) added:

Even with all these innovations, government increasingly felt the need to improve these adjustment criteria, until 1976, by means of Law 6,404, enacted on December 15, and Decree-Law 1,598, enacted on December 26, 1977, substantially changed the systematics as a whole, regarding asset adjustment and working capital, previously established.

\subsection{7-1984 - Maturing of Inflation Adjustment in Brazil}

\subsubsection{Historical and economic context}

It is noticed that, within this period, business growth boosted the diversification of production and companies began to rely on funding from various sources, however, the high inflation rates required the creation and mastering of inflation adjustment forms for those who wished to provide a company with adequate financial management. The development of studies and theories are significant chapters in this process ${ }^{2}$ and they take into account a continued dialogue between the academic and practical knowledge.

In this context, the Brazilian society was divided between reflections on politics, economics, and the passion for football. The results achieved in the 1978 FIFA World Cup allowed Argentina, which was also facing a military dictatorship, to be crowned world champion. Brazil started experiencing, in the years that followed, a strong movement for political opening.

In the political context, a strain emerged on Geisel administration, as a reaction to the movements of civil society in favor of the country's redemocratization. The last military president, General João Batista Figueiredo, approved the Amnesty Law, and party plurality was resumed. During the several manifestations, direct elections for governors, mayors, and the legislature are resumed. And the year 1984 is marked by the Campaign "Direct Elections Now" for presidential elections. 


\subsubsection{Legal context}

Decree-Law 1,452/76 provided encouragement to domestic private companies to enter into long-term funding agreements with financial institutions under control of the Federal Government for the purpose of implementation of priority projects for the country's economy, offering, as a benefit, the amount related to the value of inflation adjustment exceeding the rate of $20 \%$.

In 1976, Decree-Law 1,483 regulated the adjustment of the value of forest resources and the rights of their exploitation. In the same year, Law 6,404/76, by regulating corporations, established the minimum mandatory dividend distribution and, for companies in operation, this limit could not be less than $25 \%$ and it admitted the issue of shares without nominal value. Capital increase by using the reserve of inflation adjustment of realized capital was done without changing the number of shares issued and with increased nominal value of shares. The law also established that annual reports should take into account the effects of change in the national currency's purchasing power on the value of equity elements and the outcome in the fiscal year, and the cost of acquisition of fixed assets and balances in the account of equity should be adjusted, whose changes might be computed in the outcome of the fiscal year.

Decree-Law 1,598/77 regulated, from a fiscal perspective, Law 6,404/76 as for inflation adjustment. This decree-law recognized that the balance in the inflation adjustment account is included in the net profit of the fiscal year. In the case of assets purchased at a fixed price, for deferred payment or tranches without interest rates or inflation adjustment, the taxpayer could chose adjusting the cost of acquisition depending on the time of actual payment, provided that, if appropriate, adopted the same criterion to determine the cost of acquisition that would provide the basis to calculate the quotas of depreciation, amortization, or termination. Generally, the outcome of inflation adjustment of fixed assets and equity was booked in a special account that should be deducted (if debtor) or added (if creditor) to actual profit (taxable).

Inflation adjustment was performed having as a basis the variation in nominal value of a ORTN and it could be done in two ways (Subsidiary Ratio in ORTN and Direct Adjustment of Balances), depending on the company size and type.

For certain cases, where the balance of the inflation adjustment account was creditor (adjustment revenue), the company had the option, under certain assumptions, to defer the taxation of what the tax legislation named inflationary profit. The effective taxation of this profit occurred with the proportional realization of adjusted fixed assets, i.e. during a decrease in these assets, including due to depreciation/amortization/termination. Several transitional rules for "special" adjustment of fixed assets was also created, in 1978. Increases in capital by incorporation of profits or reserves did not suffer taxation on revenue.

Decree-Law 1,892/81 established that, in cases where the taxpayer to defer tax on capital gains for the fiscal years where they were actually received, inflation adjustment on a portion of the equity corresponding to the capital gain obtained was allowed only for the purpose of determining the actual profit, through the balance sheet date of the fiscal year where the respective gain occurred, according to the portion of price received.

Decree-Law 2,065/83 established the mandatory inflation adjustment of real estate stocks in companies with real estate activities.

\subsubsection{Context of academic research}

In 1976, in order to create the legal framework needed for strengthening the Brazilian stock market, CVM was created and the Corporate Business Law was reformulated. To achieve this aim, the Private Company Law emphasized the protection of the minority shareholder, where a major measure was creating the minimum mandatory dividend. The creation of the minimum mandatory dividend made it needed to eliminate the fictitious component of company's profit. Without an effective inflation adjustment systematics, not only in the balance sheet, but also in the annual report, companies could suffer a decapitalization, as, when silent on statements, this minimum mandatory dividend would be calculated having profit in the fiscal year as a basis (Doupnik, 1987, p. 117).

The systematics adopted was drafted by José Luiz Bulhões Pedreira and Manoel Ribeiro da Cruz Filho, based on the systematics created by themselves in 1964, which even became a decree in 1966, which has not entered into force because it has not been regulated. According to Cruz, the aim of the then new system was measuring the effects of inflation on the company's capital structure.

Doupnik (1987, p. 118) explains that the theory behind the system is that equity is protected from the corrosive effects of inflation only to the extent that it consists in fixed assets, whose values are free from fluctuations deriving from economic conditions. If equity exceeds permanent assets, a portion of capital is unprotected from inflation, resulting in a loss. Adjusting the fixed assets and the equity for inflation, and having as a counterpart the outcome for the fiscal year, the inflation adjustment systematics seeks to measure the inflationary gain or loss resulting from the of the company's capital structure.

Martins (1980) was the author who really demystified the actual meaning of the inflation adjustment account, calculated through the "simple" updating of accounts included in the fixed assets and equity. He found out that, in fact, the balance of inflation adjustment encompassed gains and losses on monetary assets and liabilities, in addition to the update of all revenues and expenses booked in the outcome of the fiscal year. And, besides, it also partially updated the initial stock balances.

Martins (1980, p. 57) claimed:

The simplicity of its calculation was replaced by a better explanation of the items included in the outcome, i.e. instead of a rather detailed adjustment of gains and losses on monetary items, revenues, and expenses within the period, stocks, etc., a single adjustment was preferred, a 
single balance. The adoption of this simplification has been practiced at the expense of non-explanation of its true meaning, something which has caused endless controversy about its usefulness and even its validity.

This text reinforced what was previously stated:

At a time when we even notice attempts to abandon a whole technique that, although not perfect or even the best existing, is quite good when compared to the previous one, it becomes a need to show its true usefulness and its true meaning, still so misunderstood among professionals, entrepreneurs, investors, analysts and politicians (Martins, 1980, p. 57).

\subsection{5-1988 - Intervention by the Brazilian Securities and Exchange Commission in the Inflation Adjustment Methodology - Implementation of Full Inflation Adjustment}

\subsubsection{Historical and economic context}

The winds of democracy were blowing in Brazil and, even indirectly, a civilian president was elected; the Brazilian Congress approved the constitutional amendment that guaranteed direct elections for all positions, 25 new political parties emerged, but studies by the Brazilian Institute of Geography and Statistics (IBGE) pointed out that the average income of the Brazilian citizen fell 12.3\% in 1985.

The following year, Plano Cruzado was announced, a financial stabilization initiative that created a new currency - Cruzado - and froze prices and wages indefinitely. As a pressure mechanism used by business owners and traders, to pressure the government in order to increase prices, the products vanished from supermarket shelves. This was the first of many economic plans that failed to reduce the inflation rates affecting the national economy.

In 1987, the second economic plan of the Sarney administration was launched. Plano Bresser, again, froze prices and wages. The Brazilian economy was so weakened that government, even temporarily, enacted a moratorium on payment of the Brazilian foreign debt, but payment was resumed that same year.

The year 1988 was marked by the promulgation of the new Brazilian Constitution, which increased individual and collective rights, and the holding of municipal elections. Inflation within this period, depending on the index we prefer, was over $1,000 \%$.

\subsubsection{Legal context}

Decree-Law 2,284/86, which established the new currency, named Cruzado, while Cruzeiro started representing one-thousandth of Cruzado, also changed the name of ORTN, which became National Treasury Bonds (OTNs) and, due to the stability of Cruzado, its value would remain unchanged for 12 months, until March 1, 1987.

Decree-Law 2,287/86 declared null and void the inflation adjustment system in annual reports provided for by Decree-Law 1.598/77 and established that, through the reference periods to be closed in 1987, the effects of change in the national currency's purchasing power on the value of equity elements and the outcomes of the reference period were computed when determining the actual profit by updates made on the basis of criteria set by the Executive Power.

Decree-Law 2,308/86 provided for inflation adjustment on the balance sheet within the reference period closing on 12/31/1986.

Decree-Law 2,341/87 provided for inflation adjustment in annual reports in a similar way to what was determined by Decree-Law 1,598/77, but with some changes. It established the variation in the value of an OTN as the basis for inflation adjustment in annual reports. It started requiring records that allow identifying the fixed assets and determining the year of their acquisition and subsequent changes. The adjustment based on an auxiliary rationale started being required for legal entities taxed on the basis of taxable profit. It provided for the concept of inflationary profit and changed the rules to recognize this profit for cases of incorporation, merger, or split-up.

Due to the intensification of inflation, the reports lost much of their information capacity. There was a need to resume the currency denominator principle, after all, it did not make any sense, for instance, to compare the components of outcome statements of different years in a currency that did not have the same purchasing power. Thus, CVM, by means of the Normative Instruction (NI) 64/86 started requiring listed companies disclose additional annual reports in a currency that has a constant purchasing power. This systematics became known as full inflation adjustment (CMI).

\subsubsection{Context of academic research}

In search of a solution to resume the information capacity of annual reports, in studies coordinated by Professor Eliseu Martins, scholars from the School of Economics, Business and Accounting of the University of São Paulo (FEA-USP) and the Foundation Institute for Accounting, Actuarial, and Financial Research (FIPECAFI) developed the systematics of CMI. This systematics consisted in adjusting all items of annual reports, something which eliminated existing remainders in the systematics then in force and, as we have seen, it was adopted by CVM. The main advantage of this systematics is the possibility to compare annual reports of different periods, providing the companies with a tool that has greater control of finance. Numerous and excellent studies on this subject were published in Boletins das Informações Objetivas (IOB), Caderno de Temática Contábil e Balanços.

\subsection{9-1995 - Signs of Fatigue and Extinction of Inflation Adjustment in Brazil \\ 2.6.1 Historical and economic context}

Seeking a solution to end the high inflation rates, various administrations have implemented economic plans 
for "stabilization". As we have seen, it started in 1986 with Plano Cruzado, followed by "Plano Bresser" in 1987. In 1989 came Plano Verão, originated by the Provisional Measure (PM) 32, another attempt to control inflation, which restored the price freeze and adopted a new currency - Cruzado Novo. During the year, there were many strikes and popular reactions against the severe economic crisis facing the country.

In 1990, Fernando Collor de Mello, first Brazilian president elected by direct vote since 1960, adopted a set of reforms aiming at the economic stabilization. This set of reforms, which ended up being named by the population as Plano Collor, brought great changes, among which we may cite: change of currency, creating Cruzeiro; lock for 18 months of balances of current accounts over Cr\$ 50,000 or Cr\$ 500,000 for private citizens or legal entities, respectively; price-fixing; wage indexation; increased taxes; and opening of the internal market to imports.

In 1994, Brazil won for the fourth time the FIFA World Cup, held in the USA, and implemented, in two phases, Plano Real. The first, by creating unidade real de valor (URV), all values of the economy and contracts that were in effect at that time were turned into the new index, which started being used as currency converter.

The second phase came with the transformation of the currency: Real. In June 1994, the monthly inflation rate reached $50 \%$, while in the second half of that year the monthly average was $2.9 \%$, something which resulted in an accumulated variation of $18.72 \%$. From then on, it was possible to view a scenario where price changes were rather controlled. The country was dealing again with inflation rates that were experienced in the late 1960s and early 1970 s.

The main rationale of the plan was focused on economy management, fighting against the so-called inertial inflation. The plan banned all types of automatic inflation adjustments in contracts, including rental and labor agreements. Then, in the end of 1995, the only law still in force that, somehow, referred us to the inflationary memory was that addressing the automatic adjustment of balance sheets. Thus, the government acted quickly and, by means of Law $9,249 / 95$, extinguished any possibility, both for corporate and fiscal effects, to recognize inflation in financial statements.

\subsubsection{Legal context}

Law 7,730/89 (Plano Verão), with the ultimate aim of de-indexing the economy, froze prices indefinitely, extinguished OTN, and declared null and void Article 185 of Law 6.404/76 and the standards of inflation adjustment provided for by Decree-Law 2,431/87. For the fiscal year 1989 , it set the value of OTN to be used.

Law 7,777/89 established the methodology to calculate the average actual value of wages, which could not be overcome by the prices of goods and services.

Law 7,799/89 established the rules for recognizing currency devaluation in annual reports in a similar way to Decree-Law 2,341/87, but with some modifications. Also started being adjusted the accounts corresponding to in- vestments in gold and payments in advance to suppliers of goods subject to inflation adjustment. The value of the National Treasury Bonus (BTN Fiscal) became the official adjustment index, measured on a daily basis. It eliminated the possibility that new forest reserves have a $6 \%$ increase besides inflation adjustment. The bookkeeping of the auxiliary rationale in BTN Fiscal started being made in daily exits. It authorized the inflation adjustment of balance sheets that served as the basis for incorporation, merger, or split-up made between December 31, 1988, and the date when this law was officially published, since it was based on the variation in the Consumer Price Index (IPC). It authorized that goods and values booked in fixed asset accounts and equity, included at the same period, could be adjusted until the month when they were paid up. Law 8,024/90 stopped using the IPC as a reference for indexing the value of BTN and BTNF, generating a gap.

Law 8,177/91 extinguished BTN and BTN Fiscal and prohibited stipulating, in contracts, any inflation adjustment clause based on price index, when concluded with a deadline or repricing period less than 1 year (originated from PM 294/91 - Plano Collor II).

Law 8,200/91 established that the inflation adjustment of annual reports should be made on the basis of monthly variation in the National Consumer Price Index (INPC).

Decree 332/91 set the rules for recognizing currency devaluation in annual reports in accordance with Decree-Law $7,799 / 89$, but with some changes. Inflation adjustment started being based on the balance updating factor (FAP) that, in turn, was updated by INPC. There was also adjustment on accounts corresponding to mutual agreement between legal entities affiliated, interconnected, parent, and subsidiary companies or those associated in any way, as well as the company credits with its partners or shareholders. It determined the inflation adjustment of profits or dividends paid or credited by outcome account within the reference period still open, booked in an account that reduces equity. The law also addressed the difference between inflation adjustment based on IPC and BTN Fiscal for 1990 and it allowed excluding this difference from the calculation basis of income tax for four consecutive years. This also addressed the special adjustment of fixed assets.

Law 8.383/91 established the fiscal reference unit (UFIR), updated on the basis of the Extended National Consumer Price Index (IPCA), as a measure of value and parameter of inflation adjustment for taxes and annual reports since 1992, correcting, somehow, the repeal of Article 185 of Law 6,404/76. In 1993, Law 8,682/93 extended the deduction of the inflation adjustment portion corresponding to the difference observed in 1990 between variation in IPC and variation in BTN Fiscal from 4 to 6 calendar years.

Law 8,920/94 established that legal entities controlled, directly or indirectly, by the government, should send, to create a reserve for unrealized profits, the credit balance of registration account of the counterparts of inflation adjustments of fixed assets and equity, limited by the net profit for the fiscal year. The amount of this reserve was excluded 
from profit for the purpose of dividend distribution and calculation of the participation of directors and administrators in outcomes.

PM 981/94 established that, since September 1994, inflation adjustment of annual reports should be made on the basis of UFIR. And Law 8,981/95 established that, since the calendar year 1995, the currency expression of UFIR should be fixed for quarterly periods.

Law 9,249/95 declared null and void the laws addressing inflation adjustment in annual reports and prohibited the use of any system to recognize inflation in these statements. Standards concerning the updating of credit rights and obligations in accordance with the exchange rates or coefficients applicable by law or contract were still in force.

\subsubsection{Context of academic research}

We may say that, in the end of 1995 , the only law that kept a relation to the inflationary memory experienced in previous periods concerned inflation adjustment in the balance sheet. Therefore, very quickly, the Federal Government extinguished it by means of Law 9,249. Then came to an end a cycle, by prohibiting, both for corporate and fiscal purposes, the recognition of inflation in annual reports.

From the viewpoint of inflation control, the measure even may be understood as needed, however, there is a need to take into account that, from the viewpoint of transparency in accounting information, it represented an actual setback, because, even knowing that inflation was significantly reduced, it is worth emphasizing that it was not and will not be eliminated in a short period of time.

Undoubtedly, the team of tax advisors of the government's economic field was aware of the measures it was taking. This may be understood by analyzing the spontaneous decrease in the income tax rates brought by Law $9,249 / 95$. The reference rate, which was $25 \%$, dropped to $15 \%$; the additional tax rates, which were $12 \%$ and
$18 \%$, dropped to $10 \%$. This analysis must be added with the fact that the same law established the deductibility, for fiscal purposes (corporate income tax and company's taxation on net profit), under certain circumstances, of payments/credits done for the purpose of interest rates on equity. Such arguments are expressed in the Explanatory Memorandum 325, enacted on August 31, 1995, prepared by the Minister of Finance, who followed up the corresponding bill.

Due to the prohibition established by Law 9,249/95, since 1996, several studies were submitted and published in conferences and professional and academic journals denouncing the distortions caused by the lack of recognition of inflation in annual reports.

We recognize the significant role played by CVM that, knowing the best informative capacity of financial statements when considering the inflationary effects, has not repealed NI 191/92 to date, which amended NI CVM 64/87, which establishes the procedures for preparation and publication of financial statements in currency with constant purchasing power.

Currently, after adopting the international accounting standards in Brazil, the Brazilian Accounting Statements Committee (CPC) seems to provide clear indications that it does not agree with what is established in the International Accounting Standard (IAS) 29 (Financial Reporting in Hyperinflationary Economies), after all, to date nothing has been done about this standard. The standard of the International Accounting Standards Board (IASB), just as the Financial Accounting Standards Board (FASB) already did, requires that inflation adjustment of financial statements should be applied only when the cumulative inflation for three consecutive years is $\geq 100 \%$ (average of $26 \%$ per year). Thus, it seems to us to be clear why CPC still has not manifested regarding IAS 29, after all, no one who have studied and understood the pernicious effects caused by the lack of recognition of inflation on the quality of financial statements can accept these limits set by IASB.

\section{CONCLUSION}

Having in mind the history of the organization - legal and practical - of inflation adjustment, we can observe that, even between the decades of 1940 and 1970, when the country experienced an inflationary process even less severe than what was observed in subsequent years, there already was a regulatory legislation and a concern - marked by the practice of accountants - to measure and reduce the impacts of devaluation of currency purchasing power on companies' assets.

Thus, thinking about providing a historical background of using this mechanism, we organized the chronology introduced in this paper on the basis of the legislation that regulated the use of inflation adjustment as a tool. By analyzing what was introduced, it is possible to see that the chronological milestones proposed go beyond a traditional division ruled by federal government administrations. The periods introduced herein, sometimes, extended over two or more administrations, and this may be understood both by fluctuations in fiscal and monetary policies not consolidated and by the delay in responding to market behavior, caused by measures of one or another administration.

Another significant aspect in this historical contextualization is allowing to understand this as a very troubled period of the national politics, permeated by strong instabilities, such as the experience of World War II, the suicide of a president, power crises, a military coup, and a very complex democratic process. Thus, we may say that the chronology derives from the analysis of the content ex- 
pressed by laws, i.e. the way how the inflation adjustment mechanism should be used. The number of laws pointed out by this article highlights and reinforces the importance and the reflection of inflation and inflation adjustment as marks of the concerns and acts of many governments over five decades, during the $20^{\text {th }}$ century.

Although historically the inflation adjustment rates may have been, at certain times, put into question, recognizing their importance for the preparation of more accurate financial statements was and still remains crucial. In 1995, after the enactment of Plano Real in 1994, even with a more effective control, inflation rates were not low enough for the complete elimination of their effects on annual reports, but the government has chosen this, and inflation adjustment was prohibited by federal law since January 1996. This is shown in the period we name as "Signs of Fatigue and Extinction of Inflation Adjustment in Brazil", which lasted from 1989 to 1995.

The whole legislation created, along with the practice either academic or by accounting professionals - allowed producing additional knowledge on using and regulating the so-called inflation adjustment tool, so that it was possible, as changes emerged in legislation, to propose technical improvements, too.

All this until the entry into force of Law 9,249/95, which may be seen from two opposing perspectives, as pointed out earlier. The first regards inflation control, which may be understood as valid, after all, the maintenance of any trace that could be regarded as a possible way to feed the inflationary process could compromise the success of the plan. And the second concerns the transparency and accuracy of accounting information. At this point, we may say that the extinction of inflation adjustment as a tool was a major setback, a step back on the possibility of controlling a company's accounts. After all, inflation has been greatly reduced, but not completely eliminated.

Therefore, currently in Brazil, we may not be sure about the quality of information provided by companies by means of their financial statements, and this is sad, because, after walking the long way described herein, we ended up lacking tools to make such information accurate.

That is our opinion, and it seems to us that this may not be disputed, the inflation control achieved by means of Plano Real did not eliminate it; this indicates that we need to find ways to create forms that allow the adequacy of annual reports to the environment of "low" inflation rates. We even agree that resurrecting the term "inflation adjustment" expression may have undesirable implications, but we cannot, as suggested by Santos and Martins (2000), stop thinking through the need to set a new mechanism. It is extremely sad that a part of our history ends in such a melancholic and inconsistent way.

\section{References}

Campos, F. A. (2003). Estratégias de desenvolvimento nacional: o papel do capital estrangeiro entre o segundo Governo Vargas e o Governo Castelo Branco (1951-1966) (Dissertação de Mestrado). Universidade Estadual de Campinas, Campinas.

Doupnik, T. S. (1987). The Brazilian system of monetary correction. In K. S. Most, Advances in international accounting (vol. 1). Londres: Jai Press.

Famá, R. (1980). Retorno sobre o investimento: sua utilização no Brasil, face à inflação e à evolução da legislação sobre a correção monetária dos demonstrativos financeiros (Dissertação de Mestrado). Universidade de São Paulo, São Paulo.

Furtado, C. (1972). Análise do "modelo" brasileiro. (2a ed.). Rio de Janeiro: Civilização Brasileira.

Gonzáles, P. (1999). Revisão crítica do sistema de correção monetária vigente na Colômbia, sob uma perspectiva da técnica desenvolvida no Brasil (Dissertação de Mestrado). Universidade de São Paulo, São Paulo.
Iudícibus, S. (1966). Contribuição à teoria dos ajustamentos contábeis. Tese de Doutorado, Faculdade de Economia, Administração e Contabilidade, Universidade de São Paulo, São Paulo, SP, Brasil.

Martins, E. (1980). Análise da correção monetária das demonstrações financeiras: implicações no lucro e na alavancagem financeira. São Paulo: Atlas.

Santos, A. (1980). Aspectos da conversão de demonstrações financeiras para moeda estrangeira (Dissertação de Mestrado). Universidade de São Paulo, São Paulo.

Santos, A., \& Martins, E. (2000 janeiro). Efeitos da inflação? Olhem bem os balanços do Banco do Brasil e do Banco do Nordeste. IOB Informações Objetivas, Temática Contábil e Balanços, 1(Boletim), 1-6.

Skidmore, T. (1988). Brasil: de Castelo a Tancredo, 1964-1985. Rio de Janeiro: Paz e Terra.

Wald, A., Simonsen, M. H., \& Chacel, J. (1970). A correção monetária. Rio de Janeiro: Apec. 